Omohyoid Muscle Syndrome の一症例

\author{
佐野 良一・中村正・稲村 博雄 \\ 前山 裕之・小池 吉郎
}

\title{
A Case of Omohyoid Muscle Syndrome
}

\author{
Ryoichi Sano, Tadashi Nakamura, Hiroo Inamura, \\ Hiroyuki Maeyama and Yoshio Koike \\ (Yamagata University)
}

Omohyoid muscle syndrome was reported by R. B. Zachary for the first time in 1969. The syndrome is characterized by remarkable distention of the omohyoid muscle during swallowing, which completely disappear at rest.

This case was a 40-year-old male who complained of discomfort of the throat and bulging of the neck during swallowing over several years, and he was diagnosed as having omohyoid muscle syndrome. The operation was performed under local anesthesia in 1990, and the omohyoid muscle was simply transected at superior belly of this muscle. Following the operation, abnormal distension during swallowing completely disappeared. The patient has had no symptoms for 9 months postoperatively and no signs of recurrence have been found.

Although the pathogenesis of omohyoid muscle syndrome is still unknown, some investigators have reported that pathological examination of the removed muscle showed myogenic degeneration. In our case, the pathological findings revealed slight degeneration of omohyoid muscle.

Key words: omohyoid muscle syndrome, myogenic degeneration, surgical treatment

はじめに

omohyoid muscle syndrome は1969年に, Zachary ${ }^{1)}$ によって最初に報告された症候群で あり，その唯一の特徴は與下時に肩甲舌骨筋が 異常に膨隆し安静時にはその膨隆が全く消失す ることである2)31.

本邦では，1983年に牧野ら4)によって報告さ れて以来，1986年渋沢ら5) の報告があるのみで 比較的稀な疾患である。

今回我々は, omohyoid muscle syndrome の
一症例を経験し，手術療法により良好な結果を 得たので報告する。

\section{症例}

症例：40歳, 男性.

主訴: 嚥下時の左頸部の膨隆, 頸部圧迫感.

家族歴：特記すべきことなし．

既往歴 : 特記すべきことなし.

現病歴：10年程前より, 嚥下時に左頸部の腫 脹が出現した。自発痛はなかったが，その後徐 々に腫脹が増大し，特にネクタイを絞める時に 
頸部圧迫感が出現してきたため, 平成 2 年 1 月 8 日当科を初診した。

現症：與下時に左側前頸部に肩甲舌骨笳の走 行に沿って無痛性の膨隆がみられ（図 1 ), 安 静時には膨隆は消失した（図 2 ), 喉頭隆起は ほぼ正中にあり，視診では頸部及び喉頭の非対 称を認めなかった。

頸部単純 X線では特に異常所見は認められな かった，食道造影検査では嚥下時に, 肩甲舌骨 筋の筋緊張の為, 喉頭全体が右に偏位するが, 特に器質的病変は認めなかった. 頸部 CT 検査 を図 3 に示したが，左の胸鎖乳突筋の内側，内 頸静脈の前方がやや肥大している所見が得られ (ム印)，この部分は肩甲舌骨筋に一致するもの

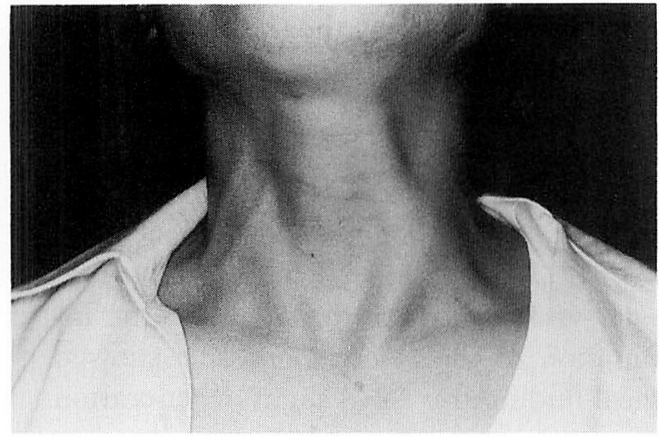

図 1 臙下時

肩甲舌骨筋に沿って膨隆が認められる。

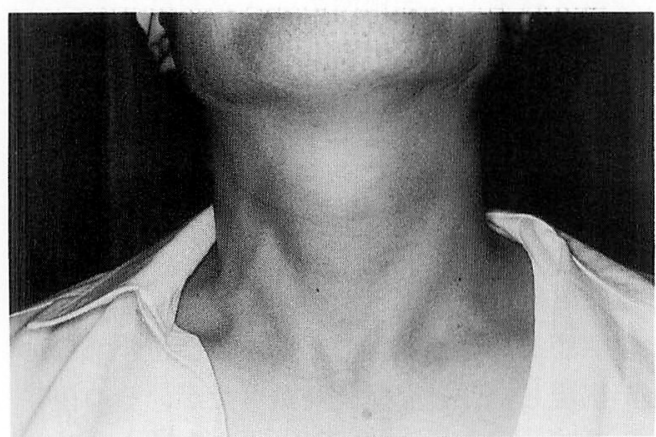

図 2 安静時

膨隆は全く消失している。
と思われた．血液生化学検査は特に異常は認め られず， $\mathrm{CPK}$ 等の筋性酵素も正常であった。

以上, 鰻下時の肩甲舌骨筋の腫脹の他には, 全く所見がなく，omohyoid muscle syndrome と診断し，患者の希望もあり手術を施行した。

手術所見：平成 2 年 6 月 28 日局所麻酔下に手 術を施行した。まず肩甲舌骨筋の膨隆部に沿っ て水平に皮切し，広頸筋の直下のレベルで皮膚 と共に剝離した。この時に畺下させると，胸鎖 乳突筋の深部で，肩甲舌骨筋が膨隆するのを確 認した．次いで，胸鎖乳突筋を側方に圧排し， 肩甲舌骨筋を明視下においた。そこで，肩甲舌

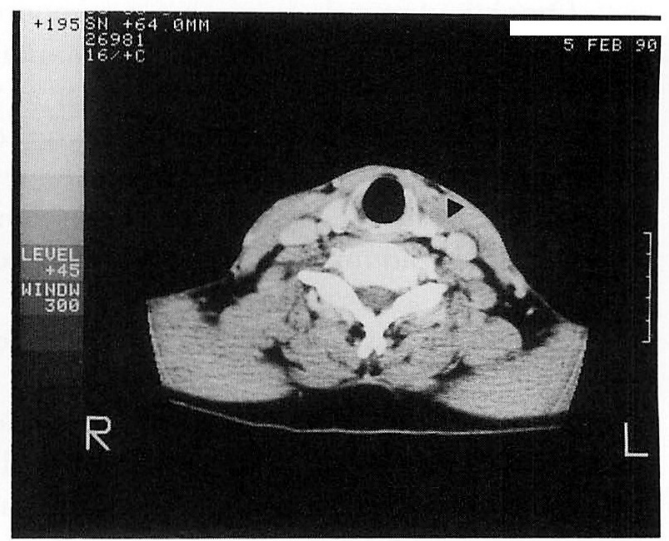

図 3 術前の $\mathrm{CT}$ 像

胸鎖乳突筋の内側（山）肩甲舌骨筋に一致して肥 大が認められる。

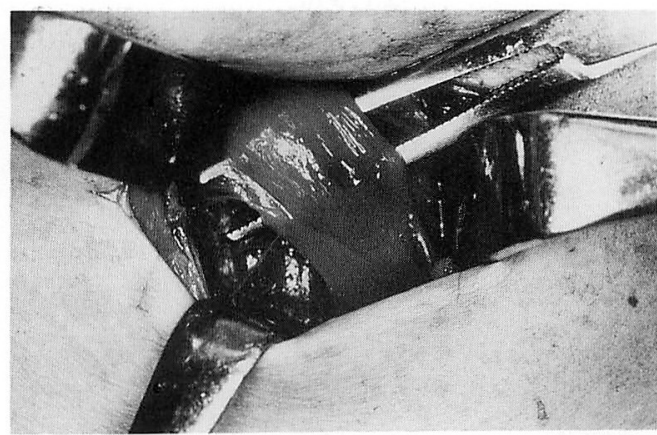

図 4 肩甲舌骨笳の周囲を剥離したところ, 通常 より筋の肥大がみられた。この段階で曣下 させたが,笳の膨隆はすでに軽減していた。 
骨筋の上腹を周囲の組織から十分に剝離し, 比 較的広、範囲にわたって露出した（図 4).こ の段階で燕下させると, 膨隆は約半分程に軽減 した．肩甲舌骨筋は通常よりかなり発達してお

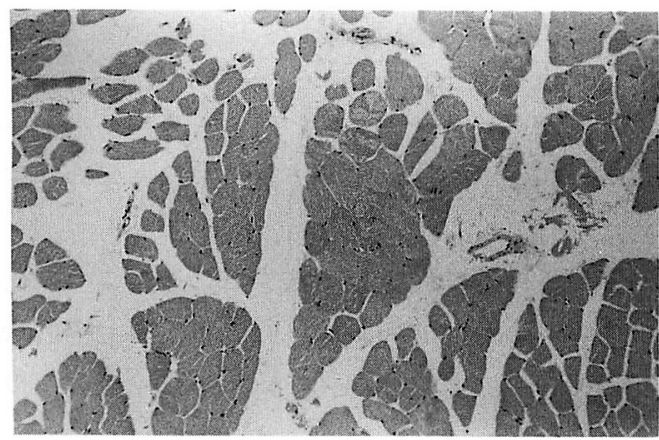

図 $5 \mathrm{HE}$ 染色 $(\times 40)$ では一部核の消失や細胞の 融合がみられた。

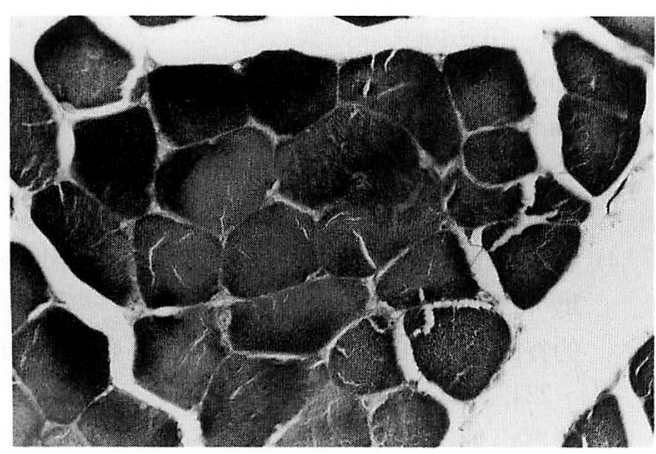

図 6 PTHA 染色 $(\times 100)$ では一様に染まらず変 性していると思われる部分があった。

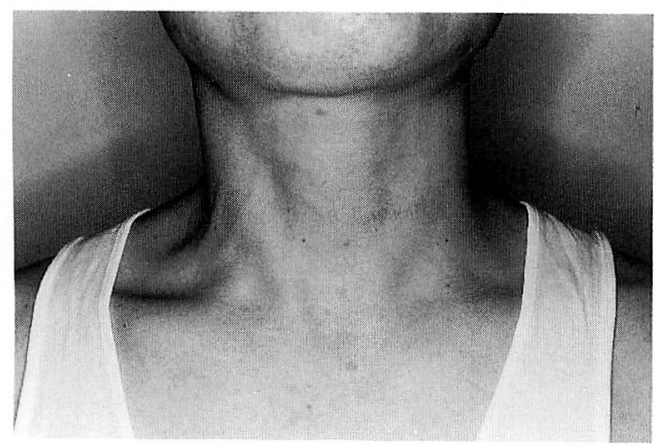

図 7 術後 9 カ月の時点での燕下時の写真 術前飞認められた膨隆は全く消失している。
り, 肉眼的には, 肩甲舌骨筋の周囲に軽い癒着 があった以外，特に異常所見は認められなかっ た。また肩甲舌骨筋の舌骨への付着部位も正常 であった．次いで，肩甲舌骨筋上腹の筋腹を単 純に切離したが，その直後より，與下時の膨隆 は全く消失した。

病理学的所見：切除した肩甲舌骨筋の一部を 標本とした. 図 5 に示した HE 染色の病理標本 では，筋絾維は一部で融合しており核の消失し ている部分が認められた. 図 6 には PTHA 染 色による病理標本を示したが，筋繊維及び筋細 胞が部分的に染まらずに变性している所見が一 部に認められた。しかし, 横紋構造は保たれて いることから，变性は比較的軽度であると思わ れた。

図 7 は術後 9 カ月を経過した時点での燕下時 の写真であるが，膨隆は完全に消失しているこ とが良くわかる．また患者の自覚症状も完全に 消失し, 現在まで再発の徵候は認められない。

\section{考察}

本症候群の臨床症状は，與下時に肩甲舌骨筋 の走行に沿って，索状及び腫瘤状の隆起がみら れ, 安静時には全く消失し, 器質的疾患がない ことで診断される。自覚症状としては, 頸部の 疼痛, あるいは咽喉頭異常感, 側頸部の腫瘤等 がある。特徵的なこととしては，いずれも燕下 時に症状が出現し, 安静時には全く症状が消失 することである11.

過去の報告によると，片側性のことが多いが， 両側性のこともあり，比較的若年者に多く，男 性に多いとされている6).

omohyoid muscle syndrome の病因は明らか ではないが，肩甲舌骨筋に特異的に起こる筋の 変性のため症状を呈するといら考光方が有力で ある. Biyuan ${ }^{6)}$ は，肩甲舌骨筋の， hyaline degeneration が重要と述べており，牧野らは 肩甲舌骨筋に myotonic atrophy を認めたとし ている。また，Zacharyl） は外傷を契機とした 一例を報告しており，牧野ら ${ }^{4)}$ の症例も同様で ある. 渋沢ら 5) は病理学的には正常であったが， 
肩甲舌骨筋の舌骨への付着部位が正常より内側 にあり, 肩甲舌骨筋の上腹が喉頭隆起へかかっ ている症例を報告している，我々の症例では筋 組織は肉眼的には肥大を認め, 顕微鏡的には横 紋構造が消失するほどではないが軽度の変性を 認めていたため, 諸家の報告の通り, 筋の変性 がこの病態の主因であることを示唆している.

しかしながら，肩甲舌骨筋の舌骨への付着部位 は正常であり, 渋沢ら5)の言うような解剖学的 な位置的異常は認められず, また, 外傷の既往 も認められなかった。 したがって, 筋の变性が 何に起因寸るのかは, 現時点では全く不明であ る.

ところで, 我々の症例では, 肩甲舌骨笳の周 囲を剥離した段階で，すでに嚥下時の膨隆は軽 減していた. 同様のことは, 牧野ら4) も述べて いる.この過程で神経支配が断烈したためと思 われるが，何らかの異常な神経支配があるのか もしれない.

omohyoid muscle syndrome は特に自覚症状 がなければ，放置しておいてよいとされる．臙 下時の疼痛や違和感が強い時, あるいは美容上 の問題から治療の対象となる時がある.

Biyuan $^{6)}$ は肩甲舌骨筋の中間腱を切離し，また 牧野ら ${ }^{4)}$ は肩甲舌骨筇の上腹を切離して嚥下時 の肩甲舌骨筋の膨隆を消失させることができた としている. 我々も局所麻酔下で燕下させなが ら, 肩甲舌骨筋の上腹を切離することで膨隆が 消失した。

肩甲舌骨筋は顎二腹筋と同様に中間腱をもつ 二腹筋で，頸神経ワナ支配であるが，與下時の 補助筋として作用していると思われている，肩 甲舌骨筋の詳細な働きは不明であるが，切離し ても，機能的には特に問題ないと思われ，現に
我々の症例でも術後に機能的な問題は生じてい ない。したがって，治療としては，手術的に筋 腹を単純に切離するだけで十分であり，技術的 にも容易である。

$$
\text { まとめ }
$$

1) 嚥下時の頸部膨隆を主訴とした omohyoid muscle syndrome の一症例を報告した。

2 ) 臨床的には嚥下時に肩甲舌骨筋の肥大を 認め, 病理学的には軽度であるが筋の变性を認 めた.

3 ) 手術時に筋腹を切離することにより, 術 直後より膨隆は消失し, 自覚症状も完全に消失 した。なお，術後 9 力月を経過しているが，再 発も認めていない.

\section{文 献}

1) Zachary RT, Young A and Hammond JDS : The omohyoid syndrome. Lancet (July) 12 : 104 105, 1969.

2) Caswell HTJR : The omohyoid syndrome. Lancet (August) $9:$ 319, 1969.

3) Voltonen E : The omohyoid syndrome. Lancet (November) $15:$ 1073, 1969.

4）牧野邦彦, 木西實, 国分典代, 他: omohyoid Muscle Syndrome一臨床的および病理学 的特徵とその成因について一。昁鼻86:721 $\sim 724,1983$.

5）渋沢三伸, 西蔦 渡, 辺士名仁: Omohyoid Muscle Syndrome の 1 症例. 日耳鼻 $89: 833$ $\sim 838,1986$.

6) Biyuan $Y:$ Omohyoid muscle syndrome. Chin Med J $93: 65 \sim 68,1980$.

$$
\left(\begin{array}{l}
\text { 別刷請求先 : 佐野良一 } \\
\text { T990-23 山形市飯田西 2-2-2 } \\
\text { 山形大学医学部耳鼻咽喉科学教室 }
\end{array}\right)
$$

